Reprod. Nutr. Dévelop., 1982, 22 (6), 931-939.

\title{
Regional distribution of steroids in the dog epididymis
}

D. BOUJARD, D. THOMAS (*), Danielle-H. GARNIER

Laboratoire de Biologie de la Reproduction (LA 256 CNRS)

(*) Laboratoire de Cytologie expérimentale (LA 256 CNRS)

Groupe de Recherches de Biologie cellulaire, Université Rennes I

Campus de Beaulieu, 35042 Rennes Cedex, France

Summary. Concentrations of $\Delta^{4}$ androstenedione, testosterone and dihydrotestosterone were measured in the post-nuclear supernatant of the dog epididymis. In addition, they were measured in the efferent ducts and the testis. From the efferent ducts to the corpus there was a significant decrease in testosterone and $\Delta^{4}$ androstenedione concentrations. On the contrary, the concentration of dihydrotestosterone increased from the efferent ducts to the corpus where this steroid predominated. The marked differences in steroid concentration along the epididymis of the dog suggested regional differences in androgen metabolism.

\section{Introduction.}

It is now well known that the maturation and storage of spermatozoa is the main function of the mammalian epididymis (Bedford, 1966 ; Orgebin-Crist, 1967, 1973). The epididymis provides the chemical environment in which the spermatozoa undergo physiological and morphological changes, leading to their functional maturation when they pass through that organ (reviewed by Bedford, 1975).

Androgens maintain the morphological and functional integrity of the epididymis (Hamilton, 1975 ; Orgebin-Crist et al., 1975). Recent works indicate that protein secreted in the epididymis could have an important role in the development of spermatozoal motility and fertilizing capacity (Fournier-Delpech et al., 1977 ; Brandt et al., 1978). Recently, Jones et al. (1980) demonstrated that the synthesis of some proteins in the rat epididymis is regulated either by testosterone or by factors in the testicular fluid; three proteins synthesized specifically in the caput are induced by testosterone. We know there is a considerable degree of variation in the concentrations of endogenous steroids in the epididymis of various mammals (Frankel and Eik-Nes, 1970; Aafjes and Vreeburg, 1972 ; Djøseland et al., 1973 ; Sulcova and Starka, 1973 ; de Larminat and Blaquier, 1978), but we have little information on the dog epididymis. To 
study protein synthesis in the dog epididymis, we have first investigated the distribution of testosterone and of some of its precursors and metabolites in rifferent parts of the dog epididymis and efferent ducts.

\section{Material and methods.}

After euthanasia with T61 (Hoechst AG, Frankfurt-am-Main, W. Germany), the epididymides and testes of mature mongrel dogs were removed and put immediately on crushed ice. The epididymides were separated from the testes at $4{ }^{\circ} \mathrm{C}$, trimmed of fat and connective tissue, measured and weighed, then rinsed in a $0.05 \mathrm{M}$ Tris $\mathrm{HCl}$ buffer, $\mathrm{pH} 7.5$, containing $0.025 \mathrm{M} \mathrm{KCl}$ and $0.01 \mathrm{M} \mathrm{MgCl}_{2}$ (TKM). Epididymal weight averaged between $1.5 \mathrm{~g}$ and $4.5 \mathrm{~g}$.

Two experiments were performed. In experiment 1 using two dogs, the caput was divided into five parts and the corpus and the cauda into two parts each (fig. 3). Since, in some cases, the caput and efferent ducts had not been well separated, a second experiment was performed using three dogs; in this experiment (experiment 2), the efferent ducts were cut into two parts, but the cauda was not studied (fig. 4). To check the different segments, a sample of each was fixed in 2.5 p. 100 glutaraldehyde, processed for electron microscopy and observed.

Each part of the epididymis was measured and weighed; the tubules, removed from the connective tissue, were minced and washed in TKM. All subsequent operations were performed at $4^{\circ} \mathrm{C}$. The tissues were homogenized with a motor-driven Teflon homogenizer at $120 \mathrm{rpm}$ in TKM and centrifuged at $1500 \times \mathrm{g}$ for $20 \mathrm{~min}$. The pellet was discarded and the post-nuclear supernatant was frozen and stored at $-20^{\circ} \mathrm{C}$ until steroid assay (Abraham, 1974). The absence of spermatozoa in the pellet, controlled by light microscopy, was chosen as a criterion of good tissue washing.

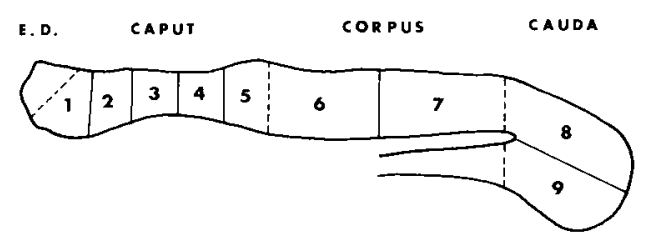

FIG. 1. - Schematic representation of dog epididymis. In the first experiment caput, corpus and cauda were divided like indicated by number on the graph. In the second experiment efferent ducts (ED) were also separated into two parts.

Protein measurement. - Protein concentration was determined in the postnuclear supernatant by the procedure of Lowry et al. (1951), using crystalline bovine serum albumin as the standard.

Steroid extraction. - After the addition of $2000 \mathrm{dpm}$ of labelled hormones for recovery estimation, the steroids were extracted from the post-nuclear supernatant with 10 volumes of an ethylacetate-cyclohexane mixture (1 v/1 v) (Garnier et al., 1978). 
Celite chromatography. - We used a modification of the procedure of Abraham et al. (1970), modified by Thorneycroft et al. (1973). Each dry extract was dissolved in isooctane at $45{ }^{\circ} \mathrm{C}$ and transferred to the column. The steroids were eluted by different isooctane-benzene mixtures, as reported in figure 2 . Five fractions : $\Delta^{4}$ androstenedione $\left(\Delta^{4}\right)$, dihydrotestosterone $(\mathrm{DHT})$, testosterone (T), $5 \alpha$-androstan $3 \alpha 17 \beta$-diol $(5 \alpha \mathrm{A} 3 \alpha)$ and $5 \alpha$-androstan $3 \beta 17 \beta$-diol ( $5 \alpha$ A $3 \beta$ ) were collected and evaporated to dryness.

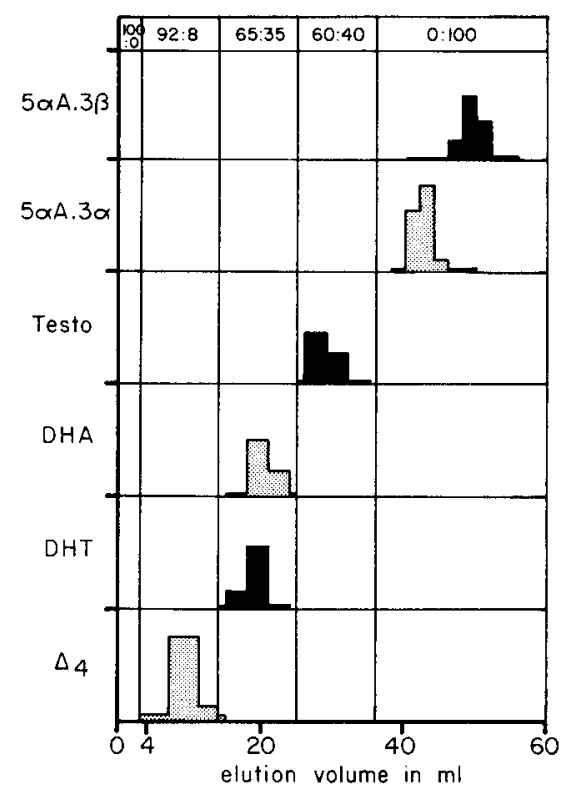

FIG. 2. - Steroid elution on celite column with propanediol as the stationary phase.

Radioimmunoassay. - We used the procedure described by Garnier et al. (1978). Anti-T and anti-DHT specificities were described in Driot et al. (1978). Anti- $\Delta^{4}$ cross-reacts only with $5 \alpha$ A $3 \alpha(7 \mathrm{p} .100)$. Anti- $5 \alpha$ A $3 \beta$ was obtained from Institut Pasteur (France). This antiserum cross-reacts with $5 \beta$ A 3 $3,17 \beta$ diol

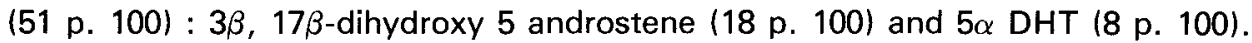

Radioimmunoassay of $5 \alpha$ A $3 \alpha$ was performed with anti-DHT. Bound and free fractions of DHT and $5 \alpha$ A $3 \alpha$ were separated by the dextran-charcoal method; these fractions of the other hormones were separated by immunoprecipitation (Terqui et al., 1973). The lower and upper limits of the standard curve were 0.005 and $1.0 \mathrm{ng}$, respectively, for T and DHT and 0.01 and $1.0 \mathrm{ng}$ for the other three hormones. The interassay coefficient of variation was less than 19 p. 100 for all steroids. The blanks (buffer and water extracted and chromatographed as above) never contained detectable immunoreactivity. Final recoveries were 90 p. 100 for $\Delta^{4}, 75$ p. 100 for DHT, 80 p. 100 for T, 50 p. 100 for $5 \alpha$ A $3 \alpha$ and $5 \alpha$ A $3 \beta$. 


\section{Results.}

We mainly studied $\Delta^{4}$ androstenedione, testosterone and dihydrotestosterone. Since the between-dog variation was great (probably due to age differences), each animal was first considered independently for graphic representation ; experiment 1 is shown on figure 3 and experiment 2 on figure 4 . The data on $\Delta^{4}, T$ and DHT were then expressed as the mean percentage of the total of the three androgens studied (fig. 5).

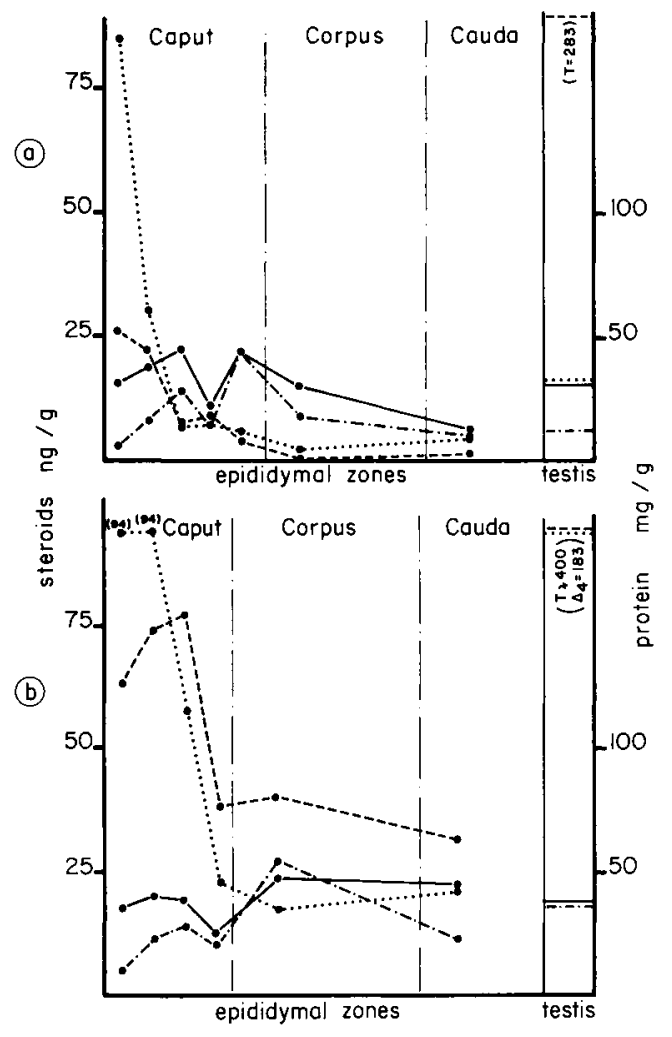

FIG. 3. - Experiment 1 : results obtained on two dogs (a and b). Steroids and protein were assayed in the post-nuclear supernatant in the caput, corpus, cauda and testis. Note the marked between-dog differences in the steroid levels. In 3b, electron microscopy showed that the first part of the caput was, in fact, the efferent ducts. Therefore, only 4 points were plotted for the caput. Steroid and protein levels in the testis are plotted as horizontal lines on the right side of the graph.

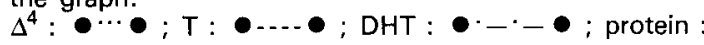

Regional androgen distribution in the efferent ducts and the epididymis. Maximal concentrations of $\Delta^{4}$ were found in the efferent ducts and the first part of the caput, but there were no significant differences between these two parts. However, the percentage of $\Delta^{4}$ significantly and progressively decreased from the efferent ducts to the corpus $(P<0.05$; two-tailed Student's t-test $)$. 


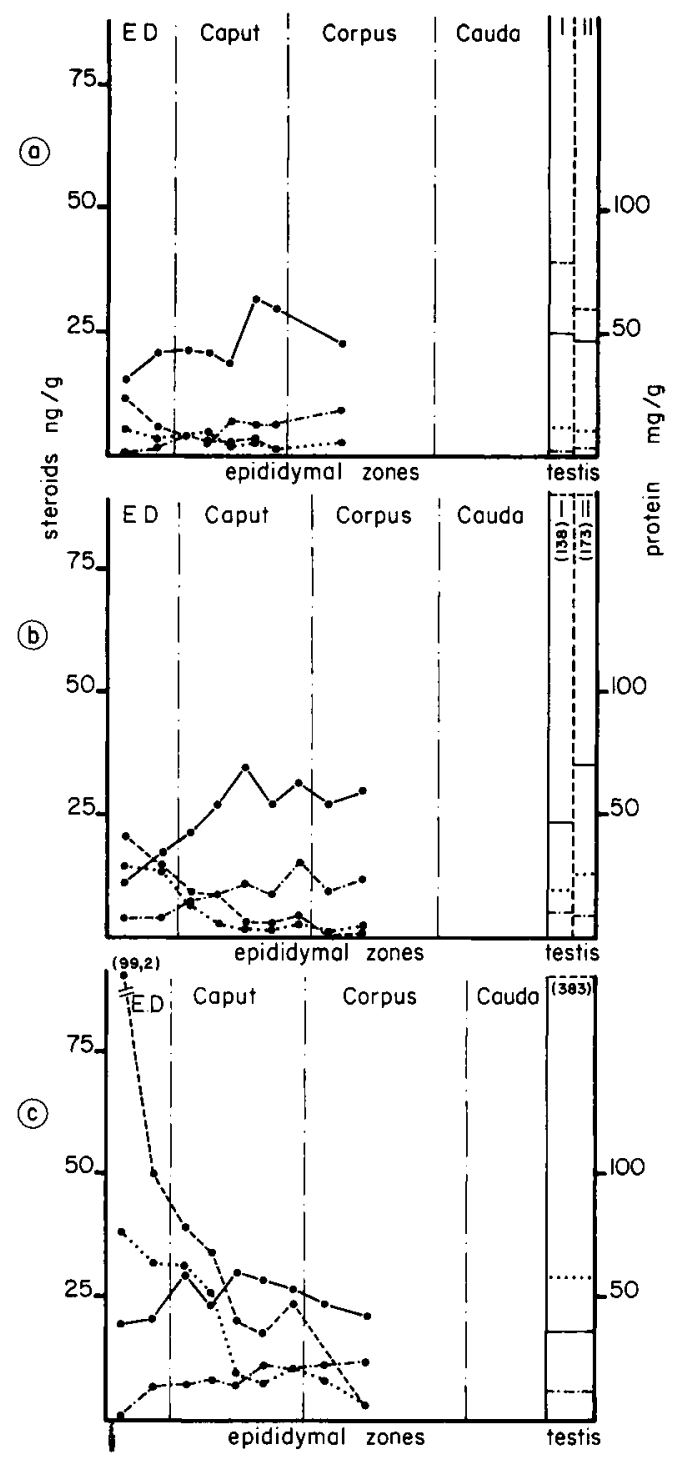

FIG. 4. - Experiment 2 : results obtained on three dogs (a, b, c). Steroids and protein were assayed in the post-nuclear supernatant in the efferent ducts (ED), caput, corpus and testis. As in experiment 1 , there are between-dog differences in the steroid levels. The highest $\Delta^{4}$ and $T$ levels are located in the efferent ducts (ED). Steroid and protein levels in the testis are plotted as horizontal lines on the right side of the graph.

$\Delta^{4}: \bullet \cdots \bullet ; \mathrm{T}: \bullet-. \bullet ; \mathrm{DHT}: \bullet-\cdot-\cdot \bullet \bullet$; protein : $\bullet-\bullet$

The maximal concentration of $T$ was located in the efferent ducts where this steroid was predominant. The $T$ concentration decreased progressively and significantly from the efferent ducts to the corpus $(P<0.05)$. No significant differences were found between the corpus and the cauda. 


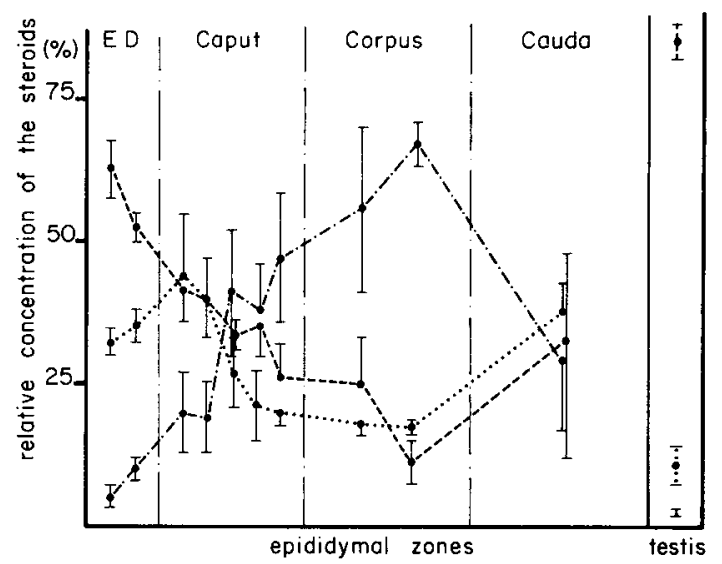

FIG. 5. $-\Delta^{4}, T$ and $D H T$ concentrations expressed as the mean percentages of the total concentration of the three androgens. SEM was calculated for the efferent ducts (ED) : $n=3$; caput and corpus : $\mathrm{n}=5$; cauda $: \mathrm{n}=2$.

$\Delta^{4}: \bullet \cdots \bullet ; \mathrm{T}: \bullet . .-\mathrm{DHT}^{\prime} \bullet-\cdot-\cdot \bullet$.

Low DHT levels were observed in the efferent ducts and the first half of the caput, while maximal levels appeared in the distal part of the caput $(3$ cases) or in the corpus ( 2 cases). The relative concentration of DHT increased significantly from the efferent ducts to the corpus $(P<0.05)$ and was inversely related to the percentage of testosterone $(r=0.93)$.

The levels of $5 \alpha$ A $3 \alpha$ in the epididymis were low (less than $5 \mathrm{ng} / \mathrm{g}$ ) but did not vary with the region. $5 \alpha$ A $3 \beta$ levels were also low $(<3 \mathrm{ng} / \mathrm{g}$ ) but two dogs showed higher levels with a maximum at the end of the efferent ducts or at the beginning of the caput.

Testicular androgens. -- The androgen levels showed between-dog variation (figs. 3, 4), but there were no significant differences between the two parts of the testis studied. $T$ was the most important androgen of the testis (85 p. 100), while DHT was weakly represented (2.6 p. 100).

Regional distribution of protein in the efferent ducts and the epididymis. As tissue composition may show regional differences, the protein content of the post-nuclear supernatant was measured. No significant divergences were found between dogs, and the mean protein concentrations $( \pm$ SEM) in the efferent ducts, caput, corpus and cauda were $35 \pm 3,53 \pm 2.4,47 \pm 3.5$ and $30 \pm$ $6 \mathrm{mg} / \mathrm{g}$, respectively.

\section{Discussion.}

$\Delta^{4}$ concentration in the dog epididymis was very reduced compared with that in the corresponding testis. However, this concentration remained high, especially in the efferent ducts and the caput epididymidis. $T$ was the major steroid in the testis, but its concentration in the epididymis appeared to be markedly reduced; a significant decrease of $\mathrm{T}$ concentration was observed 
within the epididymis from the efferent ducts to the corpus. $\Delta^{4}$ is a precursor of $\mathrm{T}$, and rat and mouse epididymidis can produce $\mathrm{T}$ from its precursor (Hamilton, 1971). This has not yet been demonstrated in the dog epididymis but our observations tend to support this possibility.

Leinonen et al. (1980) studying the human epididymis, have also reported a high concentration of $T$ precursor, especially of pregnenolone and $17 \alpha^{-}$ hydroxyprogesterone, but $\Delta^{4}$ is only a minor tissue component.

On the other hand, the testis had a relatively low DHT content, while epididymal DHT was the main steroid in the corpus. The levels of $5 \alpha \mathrm{A} 3 \alpha$ and $5 \alpha \mathrm{A} 3 \beta$, the two metabolites of testosterone in that organ, were close to the detection limit of the assay so no significant segmental distribution was demonstrated for those two steroids.

Our results suggest that $5 \alpha$ DHT would be the most important determinant of androgen action in the dog epididymis. As testicular DHT may not be the only source of this steroid hormone in the epididymis, the concentration of DHT in this organ probably reflects a local conversion from $\mathrm{T}$.

These results are confirmed by Sowell and Eik-Nes (1972) who observed large tissue retention of newly formed DHT in the dog epididymis. The DHT concentration in dog epididymis is much lower than that in rat or bull epididymis, being close to the concentration measured in the human epididymis where androgen binding protein has not been found either. Thus, DHT accumulation in the caput and the corpus may simply be related to high $5 \alpha$ reductase activity in the tissue.

Our results indicate that steroids in the dog are unequally distributed along the epididymis and form a gradient concentration. Such a gradient was also described in several species, including rat (Vreeburg, 1975 ; Kumari et al., 1980 ; Nishihara and Suzuki, 1980), rabbit (Frankel and Eik-Nes, 1970), bull and boar (Aafjes and Vreeburg, 1972; Ganjam and Amann, 1976) ; this gradient would correspond to physiological differences along the epididymis. Recently, Nicander (1981) reported a cytologically specialized, highly androgen-dependent region in the caput epididymidis of different mammals, including dog. In dog, this region corresponds to the site of high $\Delta^{4}$ and $\mathrm{T}$ levels; on the contrary, in the human epididymis, no regional steroid distribution has been demonstrated or such a region reported.

The present data provide evidence for regional differences in androgen metabolism in the dog epididymis. Although these results are preliminary, they should facilitate further studies on the molecular events controlling hormone action in the dog epididymis.

Recu en février 1982.

Accepté en juin 1982.

Acknowledgements. - Steroid analyses were performed at the "Centre de Radioimmunologie ", University of Rennes. We wish to thank Mrs. Th. Bassez, A. Cavalier and M. Mathelier for their helpful technical assistance. Anti-testosterone, anti-DHT and anti- $\Delta^{4}$ were prepared by M. Terqui, D. Garnier and Y. Cotta, INRA, Nouzilly, France. 
Résumé. Distribution des stéroïdes dans les diverses régions de l'épididyme de chien.

Chez le chien, après homogénéisation de l'épididyme, puis centrifugation, la $\Delta^{4}$ androstènedione, la testostérone et la dihydrotestostérone ont été dosées dans le surnageant post-nucléaire ; ces mesures ont été également effectuées dans les canaux efférents et dans le testicule.

Des canaux efférents au corps de l'épididyme, une décroissance significative des taux de testostérone et de $\Delta^{4}$-androstènedione est observée. Par contre, les concentrations de dihydrotestostérone augmentent jusqu'au corps, où ce stéroïde prédomine.

Cette étude montre qu'il existe des différences importantes dans la répartition des stéroïdes dans l'épididyme du chien, suggérant une régionalisation du métabolisme des androgènes.

\section{References}

AAFJES J. H., VREEBURG J. TH. M., 1972. Distribution of $5 \alpha$-dihydrotestosterone in the epididymis of bull and boar, and its concentration in rat epididymis after ligation of efferent testicular ducts, castration and unilateral gonadectomy. J. Endocrinol., 53, 85-93.

ABRAHAM G. E., 1974. Radioimmunoassay of steroids in Biological materials. Acta endoc., Suppl. $183,75,1-42$.

ABRAHAM G. E., TULCHINSKY D., KORENMAN S. G., 1970. Chromatographic purification of oestradiol 17- $\beta$ for use in radio-ligand assay. Biochem. Med., 3, 365-368.

BEDFORD J. M., 1966. Development of the fertilizing ability of spermatozoa in the epididymis of the rabbit. Exp. Zool., 163, 319-329.

BEDFORD J. M., 1975. Maturation, transport and fate of spermatozoa in the epididymis. In D. W. HAMILTON, R. O. GREEP, Handbook of physiology, Section 7, vol. V, 307-317. Williams and Wilkins, Baltimore Md.

BRANDT H., ACOTT T. S., JOHNSON D. J., HOSKINS D. D., 1978. Evidence for an epididymal origin of bovine sperm forward motility protein. Biol. Reprod., 19, 830-835.

DJØSELAND O., HANSSON V., HAUGEN H. N., 1973. Androgen metabolism by rat epididymis. Steroids, 21, 773-783.

DRIOT F. J. M., GARNIER D. H., TERQUI M., 1978. Development and validation of a " direct " radioimmunoassay for plasma testosterone in the fowl (Gallus domesticus). Gen. comp. Endocr., 36, 244-249.

FOURNIER-DELPECH S., DANZO B. J., ORGEBIN-CRIST M. C., 1977. Extraction of concanavalin A affinity material from rat testicular and epididymal spermatozoa. Ann. Biol. anim. Bioch. Biophys., 17, 207-213.

FRANKEL A. I., EIK-NES K. B., 1970. Testosterone and dehydroepiandrosterone in the epididymis of the rabbit. d. Reprod. Fertil., 23, 441-445.

GANJAM V. K., AMANN R. P., 1976. Steroids in fluids and sperm entering and leaving the bovine epididymis, epididymal tissue, and accessory sex gland secretions. Endocrinology, 99. 1618-1630.

GARNIER D. H., COTTA Y., TERQUI M., 1978. Androgen radioimmunoassay in the ram : results of direct plasma testosterone and dehydroepiandrosterone measurement and physiological evaluation. Ann. Biol. anim. Bioch. Biophys., 18, 265-281.

HAMILTON D. W., 1971. Steroid function in the mammalian epididymis. J. Reprod. Fert., suppl. 13, 89-97.

HAMILTON D. W., 1975. Structure and function of the epithelium lining the ductuli efferentes, ductus, epididymides and ductus deferens in the rat. In D. W. HAMILTON, R. O. GREEP, Handbook of physiology, section 7, vol. V, 259-301. Williams and Wilkins, Baltimore Md.

JONES R., BROWN C. R., VON GLOS K. I., PARKER M. G., 1980. Hormonal regulation of protein synthesis in the rat epididymis. Characterization of androgen-dependent and testicular ducts, castration and unilateral gonadectomy. J. Endocrinol., 53, 85-93.

KUMARI G. L., ALLAG I. S., DAS R. P., DATTA J. K., 1980. Regional differences in steroidogenesis and hormone levels in the epididymis and vas deferent of adult rats. Int. J. Andrology, 3, 267-281. 
LARMINAT M. A. de, BLAQUIER J. A., 1978. Androgen concentration and partial characterization of $5 \alpha$-reductase in the epididymis of the rhesus monkey. Steroids, 31, 129-138.

LEINONEN P., HAMMOND G. L., VIHKO R., 1980. Testosterone and some of its precursors and metabolites in the human epididymis. J. clin. Endocrinol. Metab., 51, 423-428.

LOWRY O. H., ROSEBROUGH N. J., FARR A. L., RANDALL R. J., 1951. Protein measurement with the Folin phenol reagent. $\%$ biol. Chem., 193, 265-275.

NICANDER L., 1981. A cytologically specialized, highly androgen-dependent region in the epididymal head, related to structural maturation of spermatozoa. Abstract First european workshop on molecular and cellular endocrinology of testis. Int. J. Andrology, suppl. 3, 66-67.

NISHIHARA M., SUZUKI Y., 1980. Androgen distribution in male rats. Endocrinol. jap., 27, 637-642.

ORGEBIN-CRIST M. C., 1967. Maturation of spermatozoa in the rabbit epididymis. Fertilizing ability and embryonic mortality in does inseminated with epididymal spermatozoa. Ann. Biol. anim. Bioch. Biophys., 7, 373-389.

ORGEBIN-CRIST M. C., 1973. Maturation of spermatozoa in the rabbit epididymis : effect of castration and testosterone replacement. J. exp. Zool., 185, 301-310.

ORGEBIN-CRIST M. C., DANZO B. J., DAVIES J., 1975. Endocrine control of the development and maintenance of sperm fertilizing ability in the epididymis. In D. W. HAMILTON, R. O. GREEP, Handbook of physiology, section 7, vol. V, 319-338. Williams and Wilkins, Baltimore Md.

PURVIS K., CALANDRA R., SANDER S., HANSSON V., 1978. Androgen-binding proteins and androgen levels in the human testis and epididymis. Int. J. Andrology, 1, 531-548.

SOWELL J. G., EIK-NES K. B., 1972. Formation in vivo of $5 \alpha$-dihydrotestosterone by the canine epididymis. Proc. Soc. exp. Biol. Med., 141, 827-829.

SULCOVA J., STARKA J., 1973. The metabolism of androgens in normal human testis and epididymis in vitro. Endocrinol. exp. (Bratis/), 7, 113-118.

TEROUI M., DRAY F., COTTA J., 1973. Variations de la concentration de l'oestradiol $17 \beta$ dans le sang périphérique de la brebis au cours du cycle oestral. C.R. Acad. Sci. Paris, sér. D, 277, 1795-1798.

THORNEYCROFT I. H., RIBEIRO W. O., STONE S. C., TILLSON S. A., 1973. A radioimmunoassay of androstenedione. Steroids, 21, 111-122.

VREEBURG J. T. M., 1975 . Distribution of testosterone and $5 \alpha$-DHT in rat epididymis and their concentrations in efferent duct fluid. J. Endocrinol., 67, 203-210. 